UDC 36

\title{
FROM POLICY ANALYSIS TO DELIBERATIVE-BASED POLICY RECOMMENDATION: A STUDY ON THE POLICY OF PROTECTION FOR CHILD VICTIMS OF VIOLENCE IN MALANG
}

\author{
Aristanti Wida*, Sarwono, Suryadi \\ Faculty of Administrative Sciences, University of Brawijaya, Malang, Indonesia \\ *E-mail: widaaristanti54@gmail.com
}

\begin{abstract}
This research discusses the policy analysis of protection for child victims of violence in Malang and makes the policy recommendation as a revision of the existing policy. This research was conducted based on Malang's Regional Regulation No. 12 of 2015 on Protection of Woman and Child Victims of Violence and Law No. 35 of 2014 on Child Protection. This research focused on 1) the dynamics of the policy of protection for child victims of violence in Malang, 2) the future challenge related to the policy of protection for child victims of violence in Malang; 3 ) the potential policy recommendation to improve the policy of protection for child victims of violence in Malang. This research used Critical Discourse pattern with the qualitative descriptive approach. The results of this study show that the policy of protection for child victims of violence in Malang has not been able to become a legal umbrella and a strong foundation to solve the present problem of violence. Poor coordination is also one of the factors causing less maximal implementation of child protection policy. In addition, the absence of comprehensively preventive and repressive handling strategies from Malang Government for violence cases triggers an increasing number of cases of violence. Furthermore, the future challenges related to the phenomenon of violence against children include increasing number and types of cases of violence against children, unavoidable exogenous effects, and low quality and commitment of human resources in dealing with violence issues. Considering this phenomenon, it is necessary to have the policy recommendations as a revision of the current policy, such as providing comprehensive assistance and traumatic therapy, recreating parental awareness, developing and improving the quality of human resources, and promoting social virtues in the society.
\end{abstract}

\section{KEY WORDS}

Policy analysis, policy recommendation, deliberative, protection for child, victims of violence.

The increasing number of violence against children cases perpetrated by parents/adult can be influenced by economic factors, poverty, and poor social and cultural environment. Violence against children will cause an adverse impact on the development of children both physically and psychologically. In addition, the impact of violence will also adversely affect the growth and development of children as the future generations. The child protection policies are normatively and objectively expected to solve the present problems, are able to create a protection for victims of violence, are able to create a sense of security for victims, and provide a deterrent effect for the perpetrators to create a self-control to not to commit crimes especially against children. However, up to now, the society is only faced with normative regulations and written rules without any preventive actions and strategies to overcome these problems, in which the policies have no holistic handling efforts and provide a deterrent effect for the perpetrators.

The phenomenon of violence against children has become a global and national development agenda since the signing of the Convention on the Rights of the Child 25 years ago, in which Indonesia was one of the participating countries and ratified it as Law No. 35 of 2014 on Amendment to Law No. 23 of 2002 on Child Protection. In addition, the child protection policy is also contained in the 1945 Constitution (article 28B paragraph 2) which states that each child has the right to live, grow up, and develop as well as the right to 
protection from violence or discrimination. The objectives of the child protection policies are to guarantee children's rights and to protect them from any form of violence, whether physical, psychological, or emotional abuse. The increasing number of violence against children make the government continue to pay attention to this issue.

The rise of violence against children cases takes place almost in all areas, especially urban areas. One of the cities enacted the child protection policy is Malang by the issuance of Regional Regulation No. 12 of 2015 on the Protection of Woman and Child Victims of Violence. This regional regulation was enacted because the growing number of cases of violence against women and children in Malang required comprehensive treatment. According to the Head of DP3AP2KB (Women Empowerment, Child Protection, and Population Control and Family Planning, Dinas Pemberdayaan Perempuan, Perlindungan Anak, dan Pengendalian Penduduk dan Keluarga Berencana) Malang, violence against children comes about due to several issues, such as divorce, economics, low level of parent education, and environmental, social, and cultural factors. Based on data from DP3AP2KB Malang, 18 cases of violence against children occurred in 2015, 25 cases of violence against children occurred in 2016, and 32 cases of violence against children occurred in 2017.

In order to provide services and protection for children against violence, Malang Local Government established a PPT (Integrated Service Center, PusatPelayananTerpadu) or P2TP2A (Integrated Service Centre for the Empowerment of Women and Children, Pusat Pelayanan Terpadu Pemberdayaan Perempuan dan Anak) as an integrated service center for woman and child victims of violence. The PPT includes the Department of Health, the Department of Youth and Sports Affairs, the Department of Social Affairs, the Department of Cooperation, Industry, and Trade, the Department of Population and Civil Registration, DP3AP2KB, Civil Service Police Unit, Hospital, City Police Officers, NGO, and Higher Education. Their duties include conducting legislation socialization activities to the public regarding child protection policy and providing medical services, medico-legal services, psychosocial services, legal services, and economic independence services. In addition, PPT also has a role to coordinate with each other and to work together to solve the problems.

In fact, the empirical phenomenon in the field shows that the presence of PPT in Malang has not given a significant impact in dealing with the problem. From the number of violence cases, none of the cases can be resolved thoroughly because Malang does not have a strong legal umbrella. Furthermore, the high number of violence is also caused by the apparatus does not immediately perform their task when there are reports of violence. In addition, many families or communities are still closed and reluctant to convey the case of violence, causing the difficulty for the government to solve the problem.

With these obstacles, it can be a chance for the establishment of strategies and alternatives of deliberative-based policy recommendation. Some research results show that the implementation of the deliberative democracy concept has a positive impact on the social life sustainability in many areas. Based on the explanation of the above reasons and complemented by some previous research results, the researchers aim to provide an alternative or new policy recommendations related to child protection to enable holistic treatment for cases of violence against children. Therefore, the researchers are interested to conduct research entitled "From Policy Analysis to Deliberative-Based Policy Recommendations (Study on the Policy of Protection for Child Victims of Violence in Malang)".

\section{LITERATURE REVIEW}

In this study, researchers used public policy review literature, which according to Graycar (Donovan and Jackson in Kaban, 2008, p.59) policies can be viewed from a philosophical perspective, a product, a process, and a framework. As a philosophical concept, the policy is seen as a set of desired principles or conditions. As a product, the policy is defined as a series of conclusions or recommendations. As a process, the policy refers to the way in which an organization can know what it expects in the form of the 
programs and mechanisms in reaching its products. As a framework, the policy is a process of bargaining and negotiating to formulate the issues and methods of its implementation.

Public policy analysis can be described as a form of analysis that produces and presents information in such a way that it can provide a platform for policymakers to make decisions Quade in Dunn, 2003, p. 95). Deliberative policy analysis can be interpreted as a model of the policy formulation by involving the arguments of the parties or by studying written arguments from various parties as the basis of the policy formulation (Maarten Hajer and Henderik Wagenaar in Nugroho, 2009).

\section{METHODS OF RESEARCH}

The type of research used was descriptive research with critical discourse pattern (white, 1994), while the research approach used was the qualitative approach. This research focused on 1) The dynamics of the policy of protection for child victims of violence in Malang, a) The Form of the Policy of Protection for Child Victims of Violence, b) Implementation of the Policy of Protection for Child Victims of Violence, c) Relationship between Executing Actors, d) Impact of the Policy of Protection for Child Victims of Violence, 2) The future challenges related to the policy of protection for child victims of violence in Malang, a) Increasing Number and Types of Cases of Violence against Children, b) Unavoidable Exogenous Effects, c) Low Quality and Commitment of Human Resources in handling the problem of Violence, 3) The potential policy recommendation to improve the policy of protection for child victims of violence in Malang. The research took place in Malang, while the research site was DP3AP2KB Malang. Sources of data used were primary data and secondary data. Primary data were obtained from interviews with informants, observation, and documentation. Secondary data was obtained from books, documents, journals, and scientific articles. Instruments in this study were researchers themselves. Data collection techniques were done by entering the location of research (getting in), the relationship with the subject of research (getting along), and method of collecting data (logging the data). In this research, the researcher chose the technique of data analysis in the form of discourse analysis model with critical discourse pattern (White, 1994) which has characteristic among others relying on the meaning of construct, emphasizing philosophical awareness, developing fact and value views, criticizing, and emphasizing interpretative of the actual phenomenon. Data analysis techniques used discourse analysis model with critical discourse patterns (White, 1994).

\section{RESULTS AND DISCUSSION}

\section{Dynamics of the Policy of Protection for Child Victims of Violence in Malang:}

Forms of the Policy of Protection for Child Victims of Violence. As a problem-solving effort in handling cases of violence against children, Malang Local Government issued the Malang's Regional Regulation No. 12 of 2015 on the Protection of Woman and Child Victims of Violence, which is a derivative of Law Number 35 Year 2014 on Amendment to Law Number 23 Year 2002 on Child Protection and DP3AP2KB Strategic Plan Year 2013-2018 in which there are several programs of activities to handle cases of violence against children, including the Facilitation of PPT for the child protection in Malang, socialization of RJABH, strengthening the telephone of children's friends (TESSA), facilitation of child protection institutions, facilitation of children's forums, and facilitation of child-friendly city.

Based on the results of interviews and data in the field, the policy and some of the programs are not yet considered as a solid foundation for solving and handling cases of violence against children. This is because Malang is still guided by Malang's Regional Regulation No. 12 Year 2015 on the Protection of Woman and Child Victims of Violence, while the regional regulation is still macro and not specific to cope with violence against children. This has resulted in cases of violence against children are still not getting top priority in the handling and solving efforts. 
Implementation of the Policy of Protection for Child Victims of Violence. Implementation of the Regional Regulation No. 12 of 2015 on the Protection of Woman and Child Victims of Violence is conducted by Malang Local Government by establishing P2TP2A (Integrated Service Centre for the Empowerment of Women and Children, Pusat Pelayanan Terpadu Pemberdayaan Perempuan dan Anak). P2TP2A is a technical implementation unit of DP3AP2KB which specifically deals with gender-based violence against women and children. Based on the results of the interview, it can be concluded that the implementation of the policy of protection for child victims of violence in Malang has not run optimally and comprehensively so that the impacts on the result achievements are not maximal. The establishment of P2TP2A has not been able to provide a change effect for the target group. This is still evident in the lack of awareness of the victims to report and the growing number of cases of violence against children each year. Inadequate implementation of this policy is also due to lack of coordination and low commitment among relevant stakeholders. In addition, insufficient facilities and infrastructure such as the absence of a shelter for the victims, 24-hour service, and free health services also result in thepoor implementation of child protection policy.

Relationship between Executing Actors. In the effort to implement the policy of protection for child victims of violence, Malang Local Government under the auspices of DP3AP2KB and P2TP2A cooperate and coordinate with various related institutions such as PKK (Family Welfare Development, Pembinaan Kesejahteraan Keluarga)of Malang, UPPA (Women and Children Service Unit, Unit Pelayanan Perempuan dan Anak-anak) of Malang City Police Officers, Department of Health, Department of Education, Department of Social Affairs, Puskesmas (Community Health Centre, Pusat Kesehatan Masyarakat), RSUD (Regional Public Hospital, Rumah Sakit Umum Daerah)of Malang, Sub-districtand Village of Malang, WCC of Malang, LPA (Child Protection Agency, Lembaga Perlindungan Anak) of Malang, and others. Based on the results of interviews and research data in the field, cooperation and coordination have not been running smoothly. This is because there are still many gaps and selfish attitudes of employees and agencies involved in dealing with violence cases.

Impact of the Policy of Protection for Child Victims of Violence. The policy of protection for child victims of violence in Malang has several purposes such as fulfillment of child rights in growing and developing, elimination of violence against children cases in Malang, increasing awareness for each individual about the existing cases of violence, and the establishment of a safe and convenient environment for children's growth. Based on the results of the interview, the policy of protection for child victims of violence in Malang has not had a significant impact on the elimination of violence cases, especially against children. Child protection policies as outlined in some program activities have not been able to raise public awareness for prevention and treatment after cases of violence occurred. In addition, Malang Local Government does not yet have a comprehensive handling and prevention of violence cases. It impacts on the increasing number of cases of violence against children in Malang. Malang:

Future challenges related to the policy of protection for child victims of violence in

Increasing Number and Types of Violence against Children Cases. One of the future challenges related to violence against children is the increasing number of cases of violence and the increasing variety of violence committed. Based on the results of research, challenges related to violence against children are the increasing number of cases of violence and the increasing number of motives or models that vary widely in committing the violence. The increase in violence often occurred in some areas can be caused by many factors, such as the increasingly complex economic conditions, the unfavorable environment, the low level of education that affects the unpreparedness of prospective parents to become good parents, victims of violence can become perpetrators of violence, and the increasing number of population density. Meanwhile, the increasingly varied model can be caused by technological advances in which technology can help and facilitate the perpetrators in committing acts of violence. 
The Unavoidable Exogenous Effects. Along with the development of the era, especially in this era of globalization, people cannot avoid the rapid flow of change complexity as a result of information technology advances. The future challenge of violence against children is the unavoidable exogenous effects from social life. The exogenous effects can be caused by technological advancement and globalization factor. The influence of globalization, information, and technology will impact on the emergence of life and moral degradation that will affect the social, cultural, and lifestyle of the society. The degradation of life will affect the moral behavior of people who increasingly have less care and humanity between people.

The Low Quality and Commitment of Human Resources in Handling the Problem of Violence. The existence of human resources can also be a challenge in solving violence cases in society. Excess staff quantity does not guarantee whether the existing policy can be implemented properly if it is not balanced with high quality and commitment insolving the problems. Given that in the future, the challenges of violence are so severe that it has an impact on the need for high quality and commitment of human resources.

Recommendation for the Policy of Protection for Child Victims of Violence in Malang:

Providing comprehensive traumatic assistance and therapy. Providing comprehensive assistance is urgently needed for victims as an effort to eliminate post-violence trauma. Recommendations that can be given are the presence of assistance for victims by psychiatrists and psychologists in a certain period of time in a shelter or safe house. Within a given time period, psychologists continue to treat trauma and conduct an evaluation to analyze whether child victims of violence are definitely ready to come back and socialize in the society. Once the child victims of violence have got their confidence again and enough provision of mental, then they can return to socialize with the society.

Recreating parental awareness. The role of parents in educating and raising children is a major factor in the child's growth. Parents who raise their children with affection will have an impact on the growth of quality children, but if parents do not give love in raising and educating their children then it can affect the development of the children. Based on the results of interactive discussions with some informants, it can be concluded that the violence against children in Malang is caused by many parents who do not understand their role. Most parents often do not understand what they should do to make their children grow well. Especially when finding problems in the household, parents who do not understand the role often make the child as event of their emotions. In response to the phenomenon, the researcher tries to give the policy recommendation in handling the child victims of violence is by resuscitating parental role. In this case, the researchers classify parents into two groups, prospective parents and parents who often do violence.

For prospective parents, there is a need for pre-marriage preparation in which the government can cooperate with KUA or religious department by making the bride's obligation to attend pre-marriage preparation. It is expected that pre-marriage preparation is able to minimize the unpreparedness of the parents when they encounter problems in the household. Whereas, parents who often do violence need specific assistance to be able to create a social fitness in which the perpetrators are placed temporarily in a safe house or shelter within a certain period of time accompanied by psychiatrists and psychologists. In the process, the experts try to create a social fitness for the perpetrators until they are undoubtedly stated improved by psychiatrist or psychologist so that the violence does not happen over and over.

Developing and Improving the Quality of Resources:

Human Resources. Researchers observed that the human resources handling cases of violence in Malang on average do not have expertise in the field of psychology or related to it. It will impact on the lack of maximum performance as well as efforts to prevent and handle cases of violence in Malang. Malang Local Government should do recruitment of human resources gradually by looking for employees with appropriate educational basic and have high social and loyalty. Thus, given the determined qualifications, the employees will work in accordance with their passion and high responsibility to handle the problem. 
Facilities. Adequate facilities will support the policy implementation. Based on the results of the research, it can be concluded that the implementation of thepolicyof protection for child victims of violence is due to lack of facilities and infrastructure to serve the victims. MalangLocal Government should observe and be sensitive to the needs of victims of violence, such as by the construction of a safe house (shelter), 24-hour complaints service, free health care for the victims, and others. Hopefully, adequate facilities will facilitate the provision of services for child victims of violence.

Regulation / Policy. The enactment of the policy will, of course, be based on regulation, where the regulation will be used as a strong legal basis. Based on the results of the interview, it can be concluded that the regulation governing cases of violence against children is still lacking. It impacts on the slow process of service provided for victims of violence. The regulation that must be formed immediately in Malang is related to the protection of child victims of violence, namely special regulations on children and free service regulation for victims of violence. With the establishment of these regulations, it is expected to further improve the performance of Malang Local Government in handling cases of violence against children.

Promoting Social Virtues in Society. Promoting social virtues in society aims to build ahuman civilization for future generations to prepare children with good well-being and mental so that individuals will not lose their social identity and control in the society. Development of this human civilization can be done by classifying according to age. By doing the classification, the government will easily provide the level of understanding in accordance with the development of the age of children, and replacing teaching methods in schools that are not only oriented towards values and achievements, but more oriented towards how to form honest, leadership, empathy, caring, cooperative, and high responsibility for the future.

\section{CONCLUSION}

Based on the results of research and discussion, the analysis of child protection policy has conclusions, i.e.:

1. Dynamics of the policyof protection for child victims of violence in Malang.

Malang's Regional Regulation No. 12 of 2015 on the Protection of Woman and Child Victims of Violence has not yet become a solid foundation to solve the existing problems.

Implementation of the policy of protection for child victims of violence in Malang has not run optimally and comprehensively so that the impacts on the resultachievement are not maximal. The establishment of P2TP2A has not been able to provide a change effect for the target group.

Cooperation and coordination among stakeholders under DP3AP2KB and P2TP2A have not been able to run smoothly and well. Poor coordination and cooperation between actors are caused by selfish attitude and gap between stakeholders and low commitment among stakeholders and institution to give the best service for victims of violence.

The policy of protection for child victims of violence has not had a significant impact on the change in the number of violence in which the number of violence against children continues to increase. Purposes and suggestions Malang Local Government expectshave not been able to be realized properly.

2. Future challenges related to the policyof protection for child victims of violence in Malang.

Challenges related to violence against children are the increasing number of cases of violence and motives or models that vary widely in conducting violence. It can be caused by the increasingly complicated economic conditions, the unfavorable environment, and the low level of education which affect the unpreparedness of the prospective parents to be good parents, victims of violence that can become perpetrators of violence, the increasing number of population density, and technology

Unavoidable exogenous effects of people's lives. The exogenous effects can be caused by technological advancement and globalization factor. The influence of 
globalization, information, and technology will impact on the emergence of life and moral degradation that will affect the social, cultural, and lifestyle of the community.

Human resources can also be a challenge in solving violence in society. Excess staff quantity does not guarantee whether the existing policy can be implemented properly if it is not balanced with high quality and commitment to solve the problems.

\section{SUGGESTIONS}

Creating a preventive or comprehensive preventive and comprehensive policy or strategy for handling cases of violence against children, improving and upgrading the quality of resources such as the quality of staff, services, facilities and infrastructure that can support the handling of cases of violence, providing comprehensive assistance and traumatic therapy so that the victim can recover from the trauma he suffered, recreating parental awareness, and promoting social virtues in Malang.

\section{REFERENCES}

1. Dunn, W. N. (2003). Analisis Kebijakan Publik. Yogyakarta: Gadjah Mada University Press.

2. Keban, J. T. (2008). Enam Dimensi Strategis Administrasi Publik: Konsep, Teori dan Isu. Yogyakarta: Penerbit Gava Media.

3. Nugroho, R. (2009). Public Policy. Jakarta: PT Elex Media Komputindo.

4. Peraturan Daerah Kota Malang Nomor 12 Tahun 2015 tentang Perlindungan Perempuan dan Anak Korban Kekerasan

5. Undang-Undang Nomor 35 Tahun 2014 tentang Perlindungan Anak

6. White, L. G. (1994). Policy Analysis as Discourse. Journal of Policy Analysis and Management, 13(3), 506-525. 